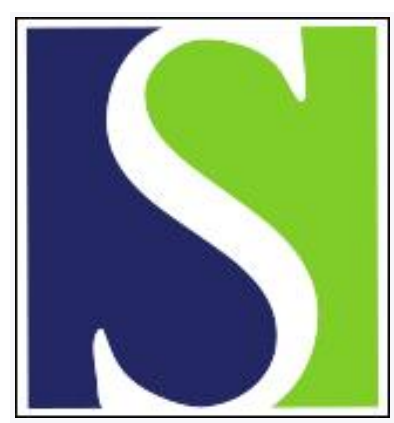

Scand J Work Environ Health 1982;8(3):222-226

https://doi.org/10.5271/sjweh.2474

Issue date: Sep 1982

Effect of exposure to organophosphorus compounds on $S$-cholinesterase in workers removing poisonous depots. by Larsen KO, Hanel HK

This article in PubMed: www.ncbi.nlm.nih.gov/pubmed/7156940

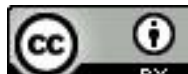




\title{
Effect of exposure to organophosphorus compounds on S-cholinesterase in workers removing poisonous depots
}

\author{
by Kay-Ole Larsen, MD, Henrik K Hanel, MSc'
}

\begin{abstract}
LARSEN K-O, HANEL HK. Effect of exposure to organophosphorus compounds on S-cholinesterase in workers removing poisonous depots. Scand $j$ work environ health 8 (1982) 222-226. Biological monitoring and the control of safety precautions against organophosphorus compounds (parathion, malathion, and methylparathion) was performed through the measurement of S-cholinesterase (E.C.3.1.1.8) in personnel removing poisonous depots. Depressions in S-cholinesterase activity where found in a majority of 62 workers in comparison to their preexposure values. After the last exposure the S-cholinesterase activity of the workers returned to the individual preexposure values; a few individuals needed about half a year for their S-cholinesterase activity to reach the preexposure level. As no workers showed either pathological values for the enzyme or poisoning symptoms, it was concluded that the measurement of S-cholinesterase activity is an adequate and sensitive method for monitoring and controlling exposure to organophosphorus compounds.
\end{abstract}

Key terms: biological monitoring, contamination, protection.

From 1957 to 1962 the chemical works of a major pesticide plant in Denmark used an area in the dunes near the plant as a waste depot for chemical compounds. During the 1970s the Danish Department of Environments became aware of this contaminated area, because fish and shellfish caught in the North Sea close to the area had been found to contain mercury. In March 1981 the Danish Government decided to have the contaminated depot removed.

The removal of the depot involved exposing men to organophosphorus compounds and therefore provided a unique opportunity to carry out the biological monitoring and controlling of safety precautions against these compounds (parathion, malathion, methylparathion).

1 Occupational Health Clinic, University Hospital, Danish Labor Inspection Service, and Department of Clinical Chemistry, Bispebjerg Hospital, Copenhagen, Denmark.

Reprints requests to: Mr HK Hanel, Department of Clinical Chemistry, Bispebjerg Hospital, Copenhagen, Denmark.

\section{Materials to be removed}

After removal of the material the content of the depots was examined for the amounts of the chemical compounds. The amounts of the following chemicals were estimated: $37 \mathrm{t}$ of parathion, $5.5 \mathrm{t}$ of methylparathion, $1.4 \mathrm{t}$ of malathion, $27 \mathrm{t}$ of thiophosphate esters, $3.7 \mathrm{t}$ of mercury compounds, and $600 \mathrm{t}$ of other unidentified organic compounds.

\section{Subjects and methods}

\section{Subjects and exposure conditions}

According to the severity of the exposure, the employees, all males, could be divided into three groups: high exposure, low exposure, and others. The men in the highexposure group worked in the contaminated area for $8 \mathrm{~h}, 5 \mathrm{~d}$ a week. The lowexposure group consisted of men who stayed for short periods of time in the contaminated area, ie, engineers, truck drivers, caretakers, and the physician. The 
group called "others" included persons with an occasional chance of exposure, ie, mechanics, electricians, and some engineers and caretakers working part-time at the depot.

Sixty-two men participated in the work, all of whom were included in our study: thirty-four in the high-exposure group, thirteen in the low-exposure group, and ten characterized as "others." Five men were excluded, three stopped work before being exposed, and two stayed less than $3 \mathrm{~d}$ at the depot.

The average age of the high-exposure group was 28 a (range $18-48$ a), that of the low-exposure group was 37 a (range $23-53$ a), and that of "others" 32 a (range $18-56$ a).

\section{Safety precautions}

All men in the contaminated area wore safety equipment according to the risk of exposure. Workers in the highly exposed group who were not operating trucks and excavators wore a neoprene suit, neoprene gloves, chemical-resistant rubber boots, and a neoprene hood with a fresh air supply. Workers in the group who operated trucks and excavators were dressed in a polyethylene suit, polyvinyl chloride gloves, and chemical-resistant rubber boots. Truck and excavator cabins were equipped with fresh air supply, and the operators wore masks with combined universal pesticide filters when moving to and fro in the contaminated area outside these cabins. The low-exposure group used the same equipment as the highly exposed group. Workers in the group characterized as "others" were in some instances equipped as the workers with high exposure, and in other instances (depending on the degree of exposure) they wore the same equipment as the truck drivers.

\section{Design}

The original plan involved a sample scheme. Blood samples would be collected before the exposure had taken place (preexposure values), and subsequent samples would then be taken after exposure of one week and continue weekly until the exposure had ceased. However, it proved impractical to follow this scheme rigorously, because the employees worked on two shifts and blood samples could not be taken during the night.

All the employees had a sample taken before they entered the contaminated area. The majority had their blood serum tested $3 \mathrm{~d}$ before the depot was opened. Thereafter serum specimens were examined during the work period at time intervals as shown in tables $1-3$, the last blood samples being taken not less than four weeks after the cessation of work. Blood samples were sometimes drawn on request, when unusual exposure was suspected.

\section{Laboratory methods}

The samples were taken in a shelter on the site. None of the men had carried out physically hard work prior to the blood sampling. The blood samples were drawn from a cubital vein into a test tube, and separated sera were sent by mail ( $1 \mathrm{~d}$ transportation) to the Department of Clinical Chemistry of the Bispebjerg Hospital for analysis. For the determination of S-cholinesterase (E.C.3.1.1.8) activity the method of Kalow \& Genest (4) was used. For the characterization of the normal phenotype of S-cholinesterase the dibucaine number (DN) was measured (4). In case of an abnormal DN, the phenotype of the enzyme was determined according to our routine procedure (8).

The reference interval for normal S-cholinesterase $(\mathrm{N}=453)$ was $680-1,560$ $\mathrm{U} / \mathrm{l}$, and for the $\mathrm{DN}(\mathrm{N}=453)$ it was 78-86. The reference interval was obtained from sera of healthy adults who were examined for the phenotype of their S-cholinesterase (8). Persons with the normal phenotype of the enzyme were included. No significant sex difference was observed for the activity of S-cholinesterase. The coefficient of variation was $0.015-0.02(1.5-2.0 \%)$.

The statistical evaluation of the data was performed according to paired observations using the Student t-test; $p$-values were calculated. For statistically significant differences a probability level of $5 \%$ was used.

Sampling records were maintained so that information about the level of S-cholinesterase was available for the individual employees. 
Table 1. S-cholinesterase activity in the high-exposure group.

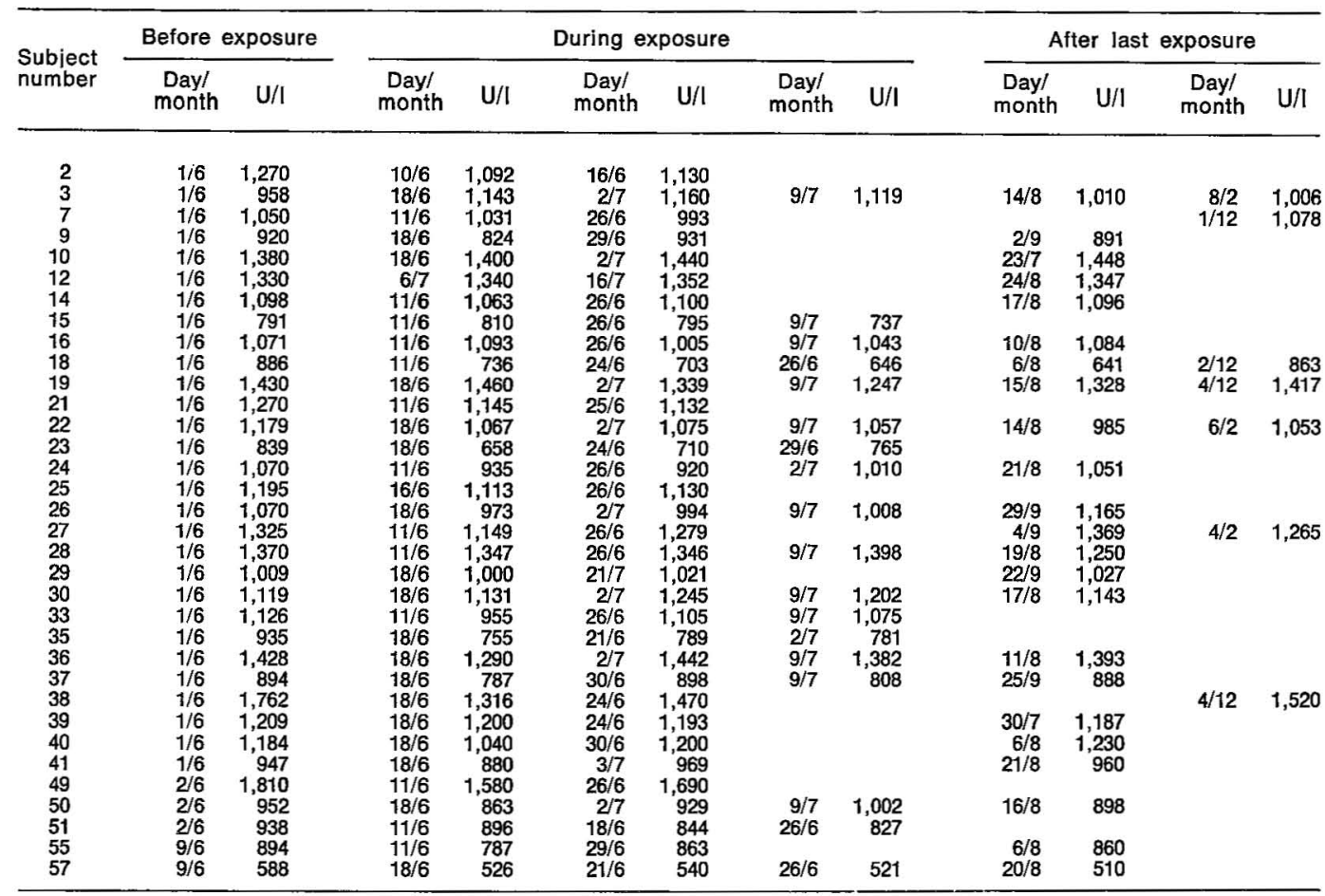

Table 2. S-cholinesterase activity in the low-exposure group.

\begin{tabular}{|c|c|c|c|c|c|c|c|c|c|c|c|c|}
\hline \multirow{2}{*}{$\begin{array}{l}\text { Subject } \\
\text { number }\end{array}$} & \multicolumn{2}{|c|}{ Before exposure } & \multicolumn{6}{|c|}{ During exposure } & \multicolumn{4}{|c|}{ After last exposure } \\
\hline & $\begin{array}{l}\text { Day/ } \\
\text { month }\end{array}$ & $U / I$ & $\begin{array}{l}\text { Day/ } \\
\text { month }\end{array}$ & $\mathrm{U} / \mathrm{I}$ & $\begin{array}{l}\text { Day/ } \\
\text { month }\end{array}$ & $U / I$ & $\begin{array}{c}\text { Day/ } \\
\text { month }\end{array}$ & $\mathrm{U} / \mathrm{I}$ & $\begin{array}{c}\text { Dayl } \\
\text { month }\end{array}$ & $U / 1$ & $\begin{array}{c}\text { Day/ } \\
\text { month }\end{array}$ & Uil \\
\hline $\begin{array}{r}1 \\
6 \\
11 \\
17 \\
20 \\
42 \\
43 \\
44 \\
45 \\
46 \\
47 \\
52 \\
53\end{array}$ & $\begin{array}{l}1 / 6 \\
1 / 6 \\
1 / 6 \\
1 / 6 \\
1 / 6 \\
1 / 6 \\
1 / 6 \\
1 / 6 \\
1 / 6 \\
1 / 6 \\
1 / 6 \\
2 / 6 \\
2 / 6\end{array}$ & $\begin{array}{r}1,234 \\
1,080 \\
1,220 \\
1,244 \\
1,740 \\
1,386 \\
982 \\
883 \\
1,057 \\
1,210 \\
1,118 \\
915 \\
1,164\end{array}$ & $\begin{array}{l}11 / 6 \\
11 / 6 \\
18 / 6 \\
11 / 6 \\
11 / 6 \\
11 / 6 \\
18 / 6 \\
18 / 6 \\
11 / 6 \\
11 / 6 \\
11 / 6 \\
11 / 6 \\
11 / 6\end{array}$ & $\begin{array}{r}1,268 \\
1,060 \\
1,135 \\
1,481 \\
1,638 \\
1,308 \\
886 \\
905 \\
873 \\
1,067 \\
1,057 \\
940 \\
1,149\end{array}$ & $\begin{array}{r}26 / 6 \\
2 / 7 \\
26 / 6 \\
26 / 6 \\
26 / 6 \\
18 / 6 \\
3 / 7 \\
24 / 6 \\
18 / 6 \\
29 / 6 \\
26 / 6 \\
18 / 6 \\
26 / 6\end{array}$ & $\begin{array}{r}1,221 \\
1,230 \\
1,179 \\
1,702 \\
1,380 \\
1,042 \\
911 \\
948 \\
1,347 \\
1,052 \\
845 \\
1,130\end{array}$ & $\begin{array}{r}9 / 7 \\
\\
9 / 7 \\
2 / 7 \\
9 / 7 \\
26 / 6 \\
9 / 7 \\
30 / 6 \\
29 / 6 \\
9 / 7 \\
3 / 7 \\
26 / 6 \\
2 / 7\end{array}$ & $\begin{array}{r}1,281 \\
1,217 \\
1,250 \\
1,702 \\
1,326 \\
1,065 \\
951 \\
959 \\
1,435 \\
1,049 \\
870 \\
1,069\end{array}$ & $\begin{array}{r}12 / 8 \\
8 / 9 \\
8 / 9 \\
10 / 8 \\
15 / 9 \\
6 / 8 \\
24 / 8 \\
2 / 10\end{array}$ & $\begin{array}{r}1,411 \\
908 \\
1,085 \\
1,079 \\
900 \\
939 \\
1,160\end{array}$ & $\begin{array}{r}10 / 2 \\
4 / 3\end{array}$ & $\begin{array}{l}1,121 \\
1,180\end{array}$ \\
\hline
\end{tabular}

Table 3. S-cholinesterase activity in the group of "others."

\begin{tabular}{|c|c|c|c|c|c|c|c|c|c|c|c|c|}
\hline \multirow{2}{*}{$\begin{array}{l}\text { Subject } \\
\text { number }\end{array}$} & \multicolumn{2}{|c|}{ Before exposure } & \multicolumn{6}{|c|}{ During exposure } & \multicolumn{4}{|c|}{ After last exposure } \\
\hline & $\begin{array}{l}\text { Day/ } \\
\text { month }\end{array}$ & $\mathrm{U} / \mathrm{I}$ & $\begin{array}{l}\text { Day/ } \\
\text { month }\end{array}$ & $u / I$ & $\begin{array}{c}\text { Day/ } \\
\text { month }\end{array}$ & $\mathrm{U} / 1$ & $\begin{array}{l}\text { Day/ } \\
\text { month }\end{array}$ & $\mathrm{U} / \mathrm{I}$ & $\begin{array}{l}\text { Day/ } \\
\text { month }\end{array}$ & $\mathrm{U} / \mathrm{l}$ & $\begin{array}{l}\text { Day/ } \\
\text { manth }\end{array}$ & $\mathrm{U} / \mathrm{I}$ \\
\hline $\begin{array}{l}4 \\
5 \\
6\end{array}$ & $\begin{array}{l}1 / 6 \\
1 / 6 \\
1 / 6\end{array}$ & $\begin{array}{r}821 \\
1,370 \\
1,080\end{array}$ & $\begin{array}{l}18 / 6 \\
11 / 6 \\
11 / 6\end{array}$ & $\begin{array}{r}744 \\
1,267 \\
1,023\end{array}$ & $\begin{array}{l}24 / 6 \\
26 / 6\end{array}$ & $\begin{array}{r}820 \\
1,385\end{array}$ & $\begin{array}{l}7 / 7 \\
9 / 7\end{array}$ & $\begin{array}{r}804 \\
1,410\end{array}$ & $\begin{array}{l}14 / 8 \\
14 / 8 \\
20 / 7\end{array}$ & $\begin{array}{r}949 \\
1,353 \\
1,088\end{array}$ & & \\
\hline 13 & $1 / 6$ & 2,117 & $18 / 6$ & 1,638 & $24 / 6$ & 1,795 & $29 / 6$ & 1,571 & $13 / 8$ & 1,752 & $3 / 12$ & 1,966 \\
\hline $\begin{array}{l}34 \\
58 \\
60\end{array}$ & $\begin{array}{r}1 / 6 \\
9 / 6 \\
12 / 6\end{array}$ & $\begin{array}{l}1,152 \\
1,280 \\
, 903\end{array}$ & $\begin{array}{l}18 / 6 \\
22 / 6\end{array}$ & $\begin{array}{r}1,310 \\
816\end{array}$ & $\begin{array}{r}26 / 6 \\
26 / 7\end{array}$ & $\begin{array}{r}1,150 \\
1,151 \\
822\end{array}$ & $\begin{array}{l}2 / 7 \\
9 / 7\end{array}$ & $\begin{array}{r}1,140 \\
832\end{array}$ & $\begin{array}{l}23 / 7 \\
24 / 9\end{array}$ & $\begin{array}{r}1,147 \\
964\end{array}$ & $4 / 2$ & 1,224 \\
\hline $\begin{array}{l}61 \\
62\end{array}$ & $\begin{array}{l}30 / 6 \\
30 / 6\end{array}$ & $\begin{array}{l}1,100 \\
1,316\end{array}$ & $\begin{array}{l}6 / 7 \\
6 / 7\end{array}$ & $\begin{array}{l}1,082 \\
1,240\end{array}$ & $16 / 7$ & 981 & & & $\begin{array}{r}12 / 8 \\
9 / 9\end{array}$ & $\begin{array}{l}1,057 \\
1,334\end{array}$ & & \\
\hline
\end{tabular}




\section{Results}

When compared with our reference interval, the S-cholinesterase of 59 of the 62 persons was normal before exposure to the contaminated area. Three men, who had depressed enzymatic activity, had abnormal DNs. Phenotyping showed that these persons' S-cholinesterase corresponded to the heterozygeous dibucaine resistant phenotype of the enzyme.

S-cholinesterase activity before, during, and after last exposure to organophosphorus compounds are shown in tables $1-3$ for the three groups. All men with the normal phenotype of the enzyme had normal activity of S-cholinesterase before exposure to the contaminated area. We therefore did not perform further examinations of their liver function.

The high-exposure group had a significant decrease in the activity of S-cholinesterase during the whole work period in comparison with the respective preexposure values; the $p$-values after the first, second, and third examinations were $\mathrm{p}<0.0005, \mathrm{p}<0.05$, and $\mathrm{p}<0.01$, respectively. After a 4-week cessation of work we also found a significant fall in the activity of the enzyme ( $p<0.05$, table 1$)$.

The low-exposure group had a significant decrease in S-cholinesterase only at the time of the second examination $(p<0.05)$. Later and after the cessation of exposure, the activity of the enzyme was reestablished $(\mathrm{p}>0.15$, table 2$)$.

In the group characterized as "others" there was a significant temporary decrease in S-cholinesterase during the first and second examination, $\mathrm{p}<0.01$ and $\mathrm{p}<0.025$, respectively; at the third examination no significant decrease in the activity of the enzyme could be found in comparison with the value before exposure $(p>0.05$, table 3). Four weeks after the last exposure the activity of the enzyme was reestablished $(\mathrm{p}>0.15$, table 3$)$.

About four weeks after the last exposure (tables 1-3) significant depressions in S-cholinesterase activity were found in a few individuals from all three groups in comparison with their respective values before exposure: five men in the high-exposure group, two in the low-exposure group, and two in the group of "others."
When reexamined later than $140 \mathrm{~d}$ after the last exposure, the S-cholinesterase activity of these men had returned to the preexposure level.

\section{Discussion}

S-cholinesterase was used as a parameter for parathion poisoning. The chosen method (4) was precise enough to detect small changes in the activity of the enzyme. We preferred the measurement of S-cholinesterase (E.C.3.1.1.8) to acetylcholinesterase (E.C.3.1.1.7.) in erythrocytes, both of which are affected by parathion, because the enzymatic activity of the former decreases before and more rapidly than the latter in parathion poisoning (1, $6,7)$. In addition the applied method allowed detection and characterization of the phenotypes of S-cholinesterase.

In the case of abnormal phenotypes of S-cholinesterase, which can have a lower enzymatic activity than the normal enzyme, the reduction in activity was taken into consideration. S-cholinesterase is a relatively stable enzyme at room temperature. Less than $10 \%$ of the activity is lost within $3 \mathrm{~d}$, and the day-to-day variation is less than $9 \%$ (2). To prevent cases of poisoning, we considered a fall in enzymatic activity of more than 20-25 \% to be due to organophosphorus compounds.

Normally, parathion causes symptoms of intoxication with depressions in S-cholinesterase activity that are greater than $30 \%$ (5); thus our threshold of $20-25 \%$ seems reasonable.

Later than $140 \mathrm{~d}$ after the last exposure to organophosphorus compounds only four man had an S-cholinesterase activity that was decreased by $10-15 \%$ in comparison with the preexposure values. These men did not show any symptoms of poisoning, and their S-cholinesterase activity was within the reference interval. Since organophosphorus compounds are lipophilic, this residual effect could be due to an accumulation in adipose tissue during exposure. The time for the normalization of S-cholinesterase after exposure depends not only on its biological halftime of 8-12 d (9), but also on the detoxication of parathion within the body. Normalization will therefore take longer than time calculated on basis of the half-time 
value.

Only a few investigations comparable with ours have been carried out previously. Grob et al (3) found that S-cholinesterase decreased at a rate of about $3-4 \%$ per day in humans after subtoxic exposure to parathion. In a similar investigation Brown \& Bush (1) found S-cholinesterase normalized within five months after the last exposure to parathion. Our results agree with the results of Brown \& Bush (1). When we found a depression of the enzyme activity of $20-25 \%$ in relation to the preexposure value, the protective equipment of the men was checked and, if necessary, improved. When the enzymatic activity decreased in spite of this, the worker was temporarily removed from exposure.

Although the men in the high-exposure group were equipped with a neoprene suit, neoprene gloves, chemically resistant rubber gloves, and a neoprene hood with a fresh air supply, the activity of the enzyme was depressed. An explanation for this depression could be that the safety equipment was inadequate. Another explanation could be that the employees did not use the safety equipment properly or that the instructions for using the safety equipment were insufficient.

Workers in the low-exposure group had decreased S-cholinesterase during the second week. It was stormy at the depot, and an explanation for the depression of the enzyme could be contamination of the whole area by poisoned sand.

No clinical symptoms of poisoning were found, and no values of S-cholinesterase were depressed to a pathological level, since all activities of the enzyme were within our reference range. Since no workers exhibited symptoms of poisoning, we conclude that the measurement of $\mathrm{S}$-cholinesterase is an adequate and sensitive method for the biological monitoring of exposure to organophosphorus com- pounds of the parathion type. Another conclusion is that the precautionary arrangements made for removal of the depot were efficient enough to prevent poisoning.

\section{Acknowledgments}

We wish to thank Prof P Lous, head of the Department of Clinical Chemistry, Bispebjerg Hospital, for his help in the planning of the investigation and for his valuable discussions. Ms G Nørgaard is thanked for her skillful technical assistance.

\section{References}

1. Brown HV, Bush SF. Parathion inhibition of cholinesterase. Arch ind hyg occup med 1(1950) 633-636.

2. Freyer JH, Steel RGD, Williams HH. Cholinesterase levels in normal human subjects. Arch ind health 12(1955) 406-411.

3. Grob D, Garlick WL, Harvey AM. The toxic effects in man of the anticholinesterase insecticide parathion (p-nitrophenyldiethyl thionophosphate). Bull john hopkins hosp 87(1950) 106-129.

4. Kalow W, Genest K. A method for the determination of atypical forms of human serum cholinesterase: Determination of dibucaine numbers. Can $\mathrm{j}$ biochem $35(1957)$ $339-346$.

5. Namba T, Nolte CT, Jackrel J, Grob D. Poisoning due to organophosphate insecticides. Am j med 50(1971) 475-492.

6. Tietz NW, ed. Fundamentals of clinical chemistry. Saunders, Philadelphia, PA 1976, pp 643-647.

7. US Department of Health, Education and Welfare. Occupational exposure to parathion. US Government Printing Office, Washington, DC 1976.

8. Viby-Mogensen J, Hanel HK. A Danish cholinesterase research unit. Acta anaesth scand 21(1977) 405-412.

9. Whittaker M. Plasma cholinesterase variants and the anaesthesist. Anaesthesia 35(1980) 147-197.

Received for publication: 13 April 1982 